\title{
Рецензія на навчальний посібник Н. В. Зінукової та Т. І. Марчук "Business English (зовнішньоекономічні аспекти)" (Дніпро : Університет імені Альфреда Нобеля, 2017. - 152 с.)
}

У період стрімкого розвитку дипломатичних і зовнішньоекономічних зв'язків перед суспільством України постає нагальна потреба в оволодінні іноземними мовами, зокрема бізнесанглійською. Таке соціальне замовлення відображається в оновлених робочих програмах щодо підготовки перекладачів, які укладені з урахуванням докорінних змін вітчизняної вищої освіти і потребують осучаснення навчального контенту для фахової філологічної підготовки.

Аналіз навчальних посібників і підручників бізнес-англійської мови засвідчує, що переважна більшість наявних видань спрямована на аспектне вправляння в проведенні комерційних перемовин або ж на написання ділових листів, що залишає поза увагою їх безпосередній взаємозв'язок й особливості перекладу задля успішного ведення бізнесу на міжнародному рівні. За таких умов рецензований навчальний посібник є не лише актуальним, а й набуває практичної значущості, оскільки спрямований передусім на застосування знань про зовнішньоекономічну діяльність у двосторонньому усному й письмовому перекладі з англійської мови українською.

Укладений авторами навчальний посібник логічно завершує курс “Ділова англійська мова” для майбутніх перекладачів (освітній ступінь “Бакалавр”). Відповідно до навчальних робочих програм укладено шість розділів, які, попри те, що кожний вміщує активний словник до теми, супроводжуються доцільними додатками. Так, у першому додатку представлено англійські бізнес-терміни й словосполучення, які подано як із варіантами перекладу, так із поясненнями щодо їхніх значень й особливостей уживання. Другий додаток - це англомовний словник-довідник економічних абревіатур із їхнім розшифруванням і роз'ясненням.

Основна частина навчального посібника охоплює шість тем: “Orders"; "Execution of Orders"; "Payments in Foreign Trade"; "Terms of Delivery"; "Types of Contracts. Negotiating Contracts”; “Complaints, Claims and Arbitration”. Об'єднавши навчальні матеріали в розділи, автори пропонують єдину чітку та логічну структуру опрацювання тем. Так, дібрані сучасні автентичні англомовні тексти репрезентують активний словник, що, безперечно, узгоджується із поданням нових лексичних одиниць у відповідному контексті. Особливої уваги заслуговує саме практична частина - вправи, запропоновані авторами з урахуванням, по-перше, професійної орієнтації суб'єктів навчання; по-друге, - чітко окресленого дискурсу майбутнього фаху.

У першому розділі, поряд із наданням прикладів замовлень на товари та послуги, подано й чіткі інструкції щодо укладання таких англомовних документів. Опрацювання запропонованого тексту й теоретичного доповнення передбачає відповіді на запитання за змістом прочитаного та щодо специфіки написання замовлень англійською мовою. Далі запропоновано тринадцять вправ для формування граматичних і лексичних навичок письма та говоріння, зокрема такі завдання, як: заповнення пропусків у текстах і реченнях; заміна словосполучень відповідними термінами-синонімами; пошук доцільної граматичної форми; перефразування окремих частин замовлень тощо. В цій частині, на нашу думку, особливого значення набувають саме вправи в усному та письмовому перекладі як з англійської мови українською, так і в зворотному напрямку.

Другий розділ посібника “Execution of Orders” вдало проілюстровано малюнками до тексту, який розкриває основи маркувань і правил пакування вантажів, товарів тощо. Тобто активний словник теми репрезентується перекладом, поясненнями, прикладами вживання в контексті, а також відповідним унаочненням. Вправи цього розділу поступово ускладнюються від двостороннього перекладу словосполучень, пошуку синонімів, заповнення пропусків до перекладу та написання тексту ділового листа за запропонованою інструкцією. Тобто в основу вправ покладено тексти англомовного комерційного листування та їх обговорення. 
Ускладнюючи кожний наступний розділ, розглянуті вище типові для цього посібника завдання автори доповнюють вправами для усного двостороннього перекладу ділових перемовин і рольові ігри. На особливу увагу заслуговують діалоги, в яких репліки з новими лексичними одиницями подано українською мовою, що передбачає їх переклад англійською. В такий спосіб, презентуючи такими діалогами частини ділових перемовин, автори моделюють для студентів типові ситуації майбутньої професійної діяльності перекладача.

Вагомим практичним здобутком авторів вважаємо розділ "Complaints, Claims and Arbitration”, зокрема його частину, присвячену врегулюванню скарг у судовому порядку. Активний словник з цієї теми вміщує терміни і мовленнєві кліше як зовнішньоекономічної, так і юридичної сфер. Усі вправи, запропоновані для опанування навчальних матеріалів розділу, спрямовані передусім на усний та письмовий переклад у типових ситуаціях, пов'язаних із виконанням бізнес-контрактів.

Таким чином, у навчальному посібнику презентовано всі етапи розвитку зовнішньоекономічних контактів, починаючи від ділового листа-замовлення до підписання повноцінного контракту, що містить супутні перемовини задля встановлення термінів постачання, визначення особливостей транспортування товарів, а також урегулювання можливих скарг і претензій за умов невиконання укладених угод.

3 огляду на вищевикладене, зазначимо, що навчальний посібник Н. В. Зінукової та Т. І. Марчук "Business English (зовнішньоекономічні аспекти)" є актуальним своєчасним виданням, яке відповідає вимогам і рівню підготовки бакалаврів спеціальності “Філологія (переклад включно)". Запропоновані авторами навчальні матеріали, завдання та словники-довідники можуть бути використані в підготовці здобувачів вищої освіти за іншими спеціальностями, а також для забезпечення навчальних англомовних програм з економіки та бізнесу.

\section{Рецензент}

кандидат педагогічних наук, доцент кафедри англійської філології та перекладу 